\title{
Adaptation of the Social Distancing Scale in the Covid-19 Era: Its Association with Depression, Anxiety, Stress, and Resilience in Turkey
}

\author{
Tuncay Oral $^{1} \cdot$ Aykut Gunlu $^{1}$
}

Accepted: 19 November 2020/Published online: 4 March 2021

(C) Springer Science+Business Media, LLC, part of Springer Nature 2021

\begin{abstract}
This study has two main objectives. The first aim is to adapt the social distancing scale (SDS) into Turkish. The second aim is to test the mediating roles of depression, anxiety, and stress on the relationship between social distance and psychological resilience. The sampling method of the study was revised as the snowball sampling. The study surveyed 843 people (481 female and 362 male) between the ages of 18 and 70 (average age 31.95) living in 51 different cities if Turkey. In the study, back-translation method was used to prepare the SDS-Turkish version. Confirmatory factor analysis results for the study showed that the single-dimension structure fits very well, as in the original form. Cronbach's alpha reliability coefficient for the scale was calculated as 0.70 . In line with the second aim of the study, the data were tested using a structural equation model analysis. Research results showed that depression, anxiety, and stress have a full mediator role in the relationship between social distancing and resilience for Turkish residents. In other words, this study eliminates social distancing's predictability of resilience by the insertion of the mediatory variable of depression, anxiety, and stress into the structural equation model.
\end{abstract}

Keywords Social distancing $\cdot$ Depression $\cdot$ Anxiety $\cdot$ Stress $\cdot$ Resilience

\section{Introduction}

The first case of the novel 2019 coronavirus occurred in Wuhan, China, on December 12, 2019. It spread to a large part of the world in a short time, about 3 months. In Turkey, the first

Aykut Gunlu

agunlu@pau.edu.tr

Tuncay Oral

toral@pau.edu.tr 
cases were seen on March 11, 2020. According to the Ministry of Health said as of October 15, 2020 , the number of cases is 340,450 , and the number of deaths is 9014 . Around this time, the virus was declared a "pandemic" as it began to threaten the whole world (World Health Organization [WHO] 2020). The word "pandemic" originates from the combination of pan and demos in the Greek language, meanings that it affects all humanity at the same time (Özkoçak et al. 2020). According to the World Health Organization, the most important feature of pandemics is the rapid spread of the virus that causes the pandemic, as well as the fact that most or all people are not immune to this virus (WHO 2020).

Coronavirus (Covid-19) is a zoonotic virus related to the "CoV" virus family, also known as severe acute respiratory syndrome (coronavirus 2, SARS-CoV-2), and can mutate easily. Since it is a new virus, it is also called the "new type coronavirus" (Çeviker and Demiray 2020; Fehr and Perlman 2015). The coronavirus enters the body through the nose, mouth, and cornea, causing discomfort in the respiratory tract and lungs. Infection of the virus is possible through cough, sneezing, and other forms of droplet transmission (Mahase 2020; Uğraş-Dikmen et al. 2020). Also, since the virus can remain suspended in the air for about $3 \mathrm{~h}$, the risk of contamination increases as a result of touching surfaces or objects touched by individuals with the disease or being in close contact with these individuals (Karcioğlu 2020). Consequently, a patient carrying the virus has a risk of infecting an average of 1.6-2.4 people. Because of this high risk, the distance between people must be at least $2 \mathrm{~m}(6 \mathrm{ft})$ to reduce the risk of transmission (Imai et al. 2020; Karcığlu 2020; Wu et al. 2020). In most countries, it is accepted as a suitable distance for maintaining a social distance of 1.5-2 m (Van Rooij et al. 2020). This practice is referred to as "social distancing." Different from total isolation, or quarantine, "social distance" is used to refer to maintaining distance from other people from the moment they leave their homes to reduce the risk of transmission of the virus (Gu et al. 2020; Wilder-Smith and Freedman 2020). Social distancing, defined by the Centers for Disease Control and Prevention in reference to Covid-19 as the practice whereby individuals "maintain a distance of at least six feet $(2 \mathrm{~m})$, from others and stay out of crowded places," has been widely adopted as a recommended means of containing the pandemic (Centers for Disease Control and Prevention [CDC] 2020). Medical experts state that social distancing is an effective means to reduce the risk of coronavirus transmission, and the practice has been applied in many countries since the outbreak of the disease (Gu et al. 2020; Tian et al. 2020; Wilder-Smith and Freedman 2020).

Another noteworthy feature of coronavirus is that the disease is seen in symptomatic and asymptomatic forms. The incubation period of the disease ranges 1-14 days, during which it is already infectious; thus, it is necessary for people who are at risk for contamination or contact to self-quarantine for 14 days (Ministry of National Health 2020). In addition, fillation applications carried out by the Ministry of Health, for people with whom infected people, are in contact. Fillation application ensures that people at risk of transmission of the virus are detected as soon as possible. Thus, the infection risk of the virus is controlled. For these reasons, scientists frequently emphasize the importance of maintaining social distance in the fight against the virus. In recent studies, the social distance rule has been a primary measure for preventing the spread of Covid-19 (Anderson et al. 2020; Niu and Xu 2020).

The coronavirus continues to spread rapidly despite all precautions. The pandemic has affected people's daily lives in many fields such as economics, education, socializing, the arts, tourism, and transportation (Deniz and Evci-Kiraz 2020). Therefore, due to the expressed characteristics of the coronavirus, and its widespread impact, the Turkish government has applied interventions to slow the rate of transmission and spread. One such intervention was the 3-week suspension of all levels of education starting from the end of the week when the 
virus appeared in Turkey, a governmental order that was later extended indefinitely due to the continuing risk of the disease. When this article written, schools were ordered to close until August 31, 2020 (Ministry of National Education [MoNE] 2020). Additional examples of such practices include the closure of all entertainment venues, cafes, restaurants, barbershops, shopping malls, and workplaces where people are at risk of close contact (Ministry of National Health 2020; Ministry of Interior [İçişleri Bakanlığı] 2020). Additional guidelines were published in a document of "14 Rules" by the Ministry of Health, including avoiding physical contact (handshakes, touch, etc.), maintaining social distance, and complying with ordinances on wearing masks. The implementation of curfew restrictions on weekends (from 00:00 on Saturday to 23:59 on Sunday), especially in Turkey's 30 metropolitan cities and Zonguldak province, aimed to ensure compliance with the social distancing rule as well. Many studies have emphasized the need for social distance in the prevention and mitigation of epidemics (Barnett-Howell and Mobarak 2020; Biçer et al. 2020; Walker et al. 2020).

In addition, precautions have been taken to prevent people from forming crowds, especially in big cities, and to maintain social distance. In this context, flexible working hours have been introduced in order to prevent people from creating intensity both in the streets and in public transportation during working hours. This issue has been enacted by the Presidency's Circular on Measures for Public Employees 2020/11. In the circular, the limit of flexible working was drawn with the statement that "methods such as distance education, flexible and rotational working can be applied to employees working in public institutions and organizations" (Official Gazette of the Turkish Republic 2020). Thus, people have tried to reduce the risk of transmitting the virus by creating density.

If countries apply social distancing in disparate ways, or if such policies are not adhered to, the virus may spread; and simulations are used to predict the spread of the virus in such cases. Adolph et al. (2020) predicted that the number of cases may increase by more than $30 \%$ if the implementation of distancing rules is delayed only 3 days in the European Union countries. A simulation conducted by the Seattle Disease Modeling Institute calculated that if no precautions are taken, the number of coronavirus-infected individuals can double between 6 and $9 \mathrm{~h}$. In addition, according to this simulation, the case and death rate may decrease by up to $92 \%$ when $50 \%$ of individuals comply with the call to "stay at home and maintain social isolation" or up to by $80 \%$ when $25 \%$ of individuals comply with this order (Karcığlu 2020). As can be seen, it is very important to comply with social distancing in the fight against the coronavirus.

Although the restrictions imposed by the Turkish Ministry of Internal Affairs mitigate the spread of the disease, they can also negatively affect the lives of individuals. Studies have noted that psychological problems such as anxiety, stress, depression, and loneliness can be triggered as a result of changes in daily life (Brooks et al. 2018; Brooks et al. 2020; Choi et al. 2020; Cudjoe et al. 2020; Duan and Zhu 2020; Hawryluck et al. 2004; Lee et al. 2016; Williams 2020; Wu et al. 2005; Zhou 2020). In addition, these individuals can face adjustment, behavioral, and mood disorders as a result of the changes in their lives (Ahorsu et al. 2020; Kaya 2020). A high risk of disease transmission can also increase anxiety levels (Asmundson and Taylor 2020; Pakpour and Griffiths 2020). A lot of changes in lifestyle are required to social distancing. This may have a significant impact on developing mental disorders (Rogowska et al. 2020). People who try to maintain social distance do not want to go out, which causes loneliness, low mood, and stress (Lewis 2020). The fact that the Covid-19 epidemic has not been brought under control also increases anxiety and stress (Pueyo 2020). Psychological resilience is defined in the literature as an individual's ability to deal with epidemic diseases, natural disasters, and trauma and to adapt to such new and uncertain 
situations (Basım and Çetin 2010; Masten and Coastworth 1998). Psychological resilience is a concept that is negatively related to anxiety, stress, and depression. Individuals with high psychological resilience are more successful than their peers at dealing with stressful factors and situations. In other words, it can be said that individuals with high levels of depression, anxiety, and stress are lacking psychological resilience (Agabi and Wilson 2005; Erarslan 2014). Studies have shown that individuals with high psychological resilience are more proactive dynamic when facing chronic ailments, natural disasters, and pandemic conditions and are less affected by such traumatic conditions (Gizir 2007; Goodman 2004; Li et al. 2012; McCubbin et al. 2002; Nakashima and Canda 2005; Samuelson et al. 2020). In the light of all these researches, it can be said that the Covid-19 era, declared as a pandemic by WHO, is an era, in which depression, anxiety, and stress can increase and also social distancing and resilience might be forced.

The theory and research outlined in the previous literature explain that physical and mental health are indistinguishable from each other during a pandemic period. The continuity of an individual's psychological health makes it easier for them to follow the rules in combating the pandemic. One of such rule is maintaining social distance. The success of guidelines surrounding curfews, public transportation, shopping malls, markets, and maintaining social distance is contingent upon individuals voluntarily and consistently participating during the period that such restrictions become the "new normal." For this reason, it seems that individuals' efforts to maintain social distance will be important to both public health and morale. The individual who maintains social distancing reduces the risk of transmission through contact and avoids emotions such as stress and anxiety. As a matter of fact, Singh (2020) found in his study that as attention is paid to social distancing, anxiety decreases while response-efficacy and health safety increase in the individual. In addition, in the study conducted by Lewis (2020), the inability of people to maintain social distancing increases stress and anxiety in the individual. Individuals may also face various positive or negative emotional situations while trying to maintain social distance. In light of these considerations, the first goal of the present study is to conduct validity and reliability analyses of the social distancing scale, developed by Van Rooij et al. (2020). In addition, in line with the explanations made in the literature, the study also aims to test of the mediator roles of depression, anxiety, and stress in the relationship between social distancing and psychological resilience.

\section{The Present Study}

Based on the aforementioned studies and theoretical assumptions, the present study tested a mediation model in which social distancing was independent variable; depression, anxiety, and stress were mediator variables; and resilience was the dependent variable. It was hypothesized that depression, anxiety, and stress have significant mediating role in the relationship between social distancing and resilience.

\section{Method}

\section{Study Group}

The sampling method of the study was revised as the snowball sampling. In the study group, there were 843 individuals, whose ages ranged between 18 and 70 with an average of 31.95 and who were 
living in 51 different cities in Turkey. Data from the research group were obtained through an online questionnaire. The demographic features of the sample group are shown in Table 1.

According to results illustrated in Tables 1, 481 participants are female (57.1\%) and 362 male (42.9\%). Participants' ages ranged from 18 to 70, with 433 people $(51.4 \%)$ between the ages of $18-30,343$ people $(40.7 \%)$ between the ages of $31-50$, and 67 people (7.9\%) between the ages of 51-70. In terms of education level, 215 (25.5\%) of the participants had completed only primary school, 151 (17.9\%) were high school graduates, and 477 (56.6\%) were university graduates. In terms of employment status, 227 (26.9\%) of the participants were students, 231 (27.4\%) were public employees, 184 (21.8\%) were private-sector employees, and $201(23.8 \%)$ were unemployed at the time of data collection.

\section{Data Collection Tools}

Study participants completed a brief personal information questionnaire that was prepared by the study authors, as well as the social distancing scale, life satisfaction scale, brief psychological resilience scale, and depression anxiety stress scale. Information on these instruments is provided in the following sections.

\section{Personal Information Form}

The first section of the survey consisted of questions created by the study researchers, requesting demographic features of the participants (e.g., gender, age, occupation, city, education level).

\section{Original Form of the Social Distancing Scale}

This scale, created by Van Rooij et al. (2020), includes four items and a single subdimension. The study used to develop the scale involved an online questionnaire distributed to 570 people, with an

Table 1 Descriptive information of the participants

\begin{tabular}{|c|c|c|}
\hline Demographic features & $\mathrm{f}$ & $\%$ \\
\hline \multicolumn{3}{|l|}{ Gender } \\
\hline Female & 481 & 57.1 \\
\hline Male & 362 & 42.9 \\
\hline \multicolumn{3}{|l|}{ Age } \\
\hline $18-30$ & 433 & 51.4 \\
\hline $31-50$ & 343 & 40.7 \\
\hline $51-70$ & 67 & 7.9 \\
\hline \multicolumn{3}{|l|}{ Education } \\
\hline Primary school & 215 & 25.5 \\
\hline High school & 151 & 17.9 \\
\hline Bachelor's degree & 477 & 56.6 \\
\hline \multicolumn{3}{|l|}{ Job } \\
\hline Student & 227 & 26.9 \\
\hline Public employees & 231 & 27.4 \\
\hline Private sector & 184 & 21.8 \\
\hline Unemployed & 201 & 23.8 \\
\hline \multicolumn{3}{|l|}{ Marital status } \\
\hline Married & 375 & 55.5 \\
\hline Single & 468 & 44.5 \\
\hline
\end{tabular}


average age of 34.5 , living in 35 of the 50 American states. The items are presented on a 7-point Likert-type scale with responses ranging from never (1) to always (7). An example scale item is "I keep a safe distance from people outside of my direct household." On this scale, items 1, 3, and 4 are coded as the reverse. High scores obtained from the scale indicate that the individual pays attention to social distancing and follows social distance rules. In the original form of the scale, Cronbach's alpha reliability coefficient was calculated as 0.76 . In the analysis conducted with the data collected within the scope of this study, Cronbach's alpha internal consistency was determined to be 0.70 .

\section{Life Satisfaction Scale}

The scale was developed by Diener et al. (1985) to gauge individuals' life satisfaction and was adapted into Turkish by Dağlı and Baysal (2016). Questions are scored on a 5-point Likert-type scale with responses ranging from I do not agree at all (1) to I totally agree (5). This scoring structure was preserved in the Turkish adaptation of the scale. The reliability of the adapted scale was calculated as 0.88 . Considering the compliance values of the scale's confirmatory factor characteristics, the value of $\chi^{2} / \mathrm{sd}$ was determined as 1.17 , NFI value as 1.00 , SRMR value as 0.02 , GFI value as 0.99 , and AGFI value as 0.97 . These calculations demonstrated show that the scale has good fit values. In the analysis conducted with the data collected within the scope of this study, Cronbach's alpha internal consistency was determined to be 0.82 .

\section{Brief Psychological Resilience Scale}

The brief psychological resilience scale is scale with six items, presented on a 5-point Likert type scale, developed by Smith et al. (2008) and adapted by Doğan (2015). Options for response range from not suitable at all (1) and completely suitable (5). The Turkish version of the instrument consists of six items with a single dimension. Items 2, 4, and 6 on the scale are coded as the reverse. High scores from the scale indicate high levels of psychological resilience. The scale is single factor, with a lowest possible score of 6 and highest score of 30 . The reliability of the adapted was calculated as 0.80 . According to the confirmatory factor analysis results, the value of $\chi^{2} /$ sd was 1.83 , NFI value was 0.99 , SRMR value was 0.03 , GFI value was 0.99 , and AGFI value was 0.96 . These calculations demonstrate that the scale has good fit values. In the analysis conducted with the data collected within the scope of this study, Cronbach's alpha internal consistency was determined to be 0.79 . .

\section{Depression Anxiety Stress Scale}

The first form of the depression anxiety stress scale (DASS) was created by Lovibond and Lovibond (1995) with 42 items. Questions are sorted into three subdimensions (depression, anxiety, and stress), each with 14 items, and are scored on a 4-point Likert-type scale $(0=$ never, 1 = sometimes, 2 = quite often, and $3=$ always). Validity and reliability studies of an adapted scale with 21 items were performed, and thus the DASS-21 form was created (Henry and Crawford 2005; Mahmoud et al. 2012). Y1lmaz et al. (2017) adapted the DASS-21 form to Turkish. The reliability of the adapted scale was determined to be 0.82 for the depression subscale, 0.81 for the anxiety sub-scale, and 0.76 for the stress sub-scale. Considering the compliance values of the scale's confirmatory factor characteristics, the value of $\chi^{2} / \mathrm{sd}$ was determined as 2.58, NFI value as 0.98 , SRMR value as 0.04 , GFI value as 0.93 , and AGFI value as 0.91 . These values show that the scale has good fit values. In the analysis conducted 
with the data collected within the scope of this study, Cronbach's alpha internal consistency was determined to be 0.89 for the depression sub-scale, 0.86 for the anxiety sub-scale, and 0.87 for the stress sub-scale.

\section{Study 1}

\section{Process}

Before beginning an adaptation study to modify a scale to a new national and cultural context, ethical principles dictate that researchers must obtain permission from the author who developed the original scale. Thus, the researchers designing the present study e-mailed Van Rooij et al. (2020) to obtain permission to conduct validity and reliability studies for the adapted scale. After these permissions were obtained, five academics from the university's English language department translated the scale into Turkish. The scale was then again translated into English through a "back-translation method." The researchers then examined the consistency between this back-translated English form and Van Rooij et al. (2020) original English form. After the scales were deemed consistent, the meaning structure of the adapted scale was checked by a specialist from the Turkish Language and Literature department, and thus the final version of the scale was created. According to the findings obtained in the De Pedraza et al. (2020) research, there is positive correlation between life dissatisfaction and Covid-19 pandemic. And also in the other studies, there are negative correlations between life satisfaction and Covid-19 stress (Trzebiński et al. 2020) and severity of Covid-19 (Zhang et al. 2020). In accordance with this findings, when making the adaptation of the social distancing scale in the Covid-19 era, the use of life satisfaction scale complies with the literature.

\section{Data Analysis}

Preliminary Analysis Before starting data analysis, the data set was checked for missing data. A reversal process was carried out in relation to the items with reverse scores in the scales used. After determining that the data set had a normal distribution, the research data were analyzed. The analysis of the scale's structural validity was carried out using the confirmatory factor analysis method, while Cronbach's Alpha technique was preferred for reliability analysis. Before starting CFA, it was examined whether the data set is suitable for CFA (sample size, multiple linearity, multicollinearity). It was found that the data set was suitable for CFA. Therefore, maximum likelihood method was used in CFA. The life satisfaction scale was used for convergent and discriminant validity. In addition, after the adaptation of the scale, the theoretical structure of the scale was tested with research in the second stage of the study. The validity and reliability used IBM's SPSS and AMOS graphic programs.

\section{Results}

\section{Structure Validity}

When adapting a measurement tool to another culture, confirmatory factor analysis is used to determine the structure of the original scale in the adapted culture (Çokluk et al. 2014; Seçer 
2015). The fit indices, frequently used in the confirmatory factor analysis method, are chisquare fit $\left(\chi^{2}\right)$ and ratio of chi-square to the degree of freedom $\left(\chi^{2} / \mathrm{sd}\right)$, as well as CFI, RMSEA, GFI, AGFI, and SRMR (Bayram 2016; Brown 2006). The model fit indices obtained in the confirmatory factor analysis performed to determine the construct validity of the social distancing scale are presented in Table 2, while the path diagram and factor loads are presented in Fig. 1.

According to the results illustrated in Table 2, it can be said that the social distancing scale has the best possible fit value (Bayram 2016; Brown 2006; Schumacker and Lomax 2010; Şimsek 2007). From the obtained results in Fig. 1, it might be said that the factor loadings are within acceptable limits. Some of them are low (.38 and .47).

\section{Convergent and Discriminant Validity}

The life satisfaction scale developed by Diener et al. (1985) and adapted to Turkish by Dağl1 and Baysal (2016) was used in the convergent and discriminant validity study of the social distancing scale. The life satisfaction scale was preferred as it is a scale related to the age level of the research group that measures a concept related to social distancing. According to the results of the analysis, a positive $(r=.12, p<.01)$ correlation was found between social distancing and life satisfaction.

\section{Reliability Analysis}

Corrected item-total correlations and Cronbach's alpha internal consistency coefficient analyses were used to determine the reliability of the social distancing scale. The adjusted itemtotal correlations of the scale had values between .33 and .65 . According to the analyses, Cronbach's alpha reliability coefficient of the scale was calculated as 0.70 .

\section{Study 2}

\section{Results}

The second aim of this study is to examine the mediating roles that depression, anxiety, and stress play in the relationship between social distancing and psychological resilience. The data for this part of the study were obtained from the same sample group used in study 1. Since sufficient information was given in study 1 about the demographic characteristics of the sample group, it was not necessary for these participants to supply that information again. Before analysis, the distribution of the observed variables in the data was examined by considering the skewness and kurtosis coefficients and also critical ratio as in study 1 (see Table 3). The skewness and kurtosis values of the variables ranged between -2 and +2 , and

Table 2 Social distancing scale model fit indices

\begin{tabular}{lllllll}
\hline & $\chi^{2} / \mathrm{sd}$ & CFI & RMSEA & GFI & AGFI & SRMR \\
\hline Good fit values & $<3$ & $.90-1.00$ & $.00-.05$ & $.90-1.00$ & $.90-1.00$ & $.00-.05$ \\
Model fit indices & .65 & 1.00 & .00 & .99 & .99 & .00 \\
\hline
\end{tabular}




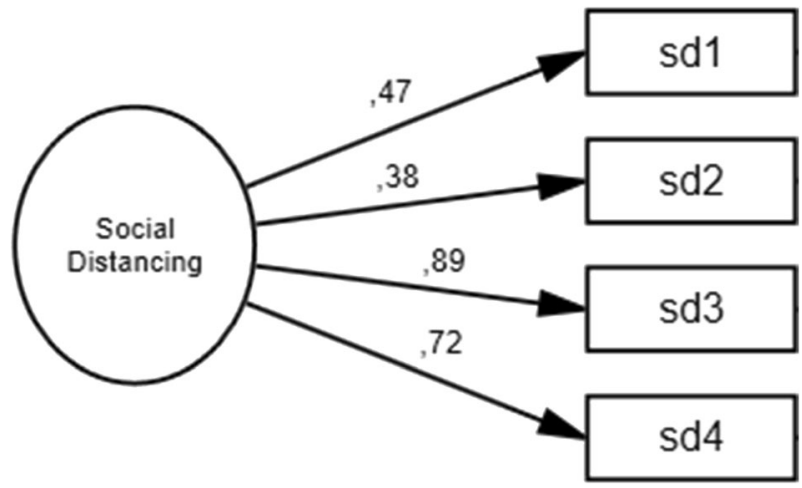

Fig. 1 Social distancing scale path diagram and factor loads

the critical ratio (C.R.) values of the variables was lower than +8 and thus exhibited normal distribution (Kline 2011; Morgan et al. 2004). Subsequent analysis involved generating descriptive statistics and revealing the relationships between variables. Then, the potential mediating roles of depression, anxiety, and stress in the relationship between social distancing and psychological resilience were tested with the structural equation model.

\section{Descriptive Statistics}

Considering the correlations between variables, a positive significant $(r=.12, p<.01)$ relationship was found between social distance and psychological resilience and a negative significant relationship between social distance and depression $(r=-.19, p<.01)$, as well as between anxiety $(r=-.23, p<.01)$ and stress $(r=-.19, p<.01)$. The data obtained are presented in Table 4.

\section{Test of the Structural Model}

Baron and Kenny (1986) explain that there is a significant relationship between the structural equation model and the dependent (resilience), independent (social distancing), and mediator (depression, anxiety, and stress) variables used to test the mediating variable. As seen in Table 4, there are significant relationships between the variables examined in this study. Considering the findings in Table 4, it can be said that the results reached are suitable for structural equation analysis (Şimsek 2007). According to the analysis of the structural equation model carried out for the mediating effect of depression $\left(\chi^{2} / \mathrm{sd}=4.13, p<.001, \mathrm{CFI}=.93\right.$, RMSEA $=.06, \mathrm{GFI}=.93, \mathrm{AGFI}=.92, \mathrm{SRMR}=.06$ ), the results were found to have acceptable fit indices. According to the analysis of the structural equation model for the mediating effect

Table 3 Statistics on the items of the social distancing scale

\begin{tabular}{llrrrr}
\hline Item no. & Corrected item-total correlation & M (SD) & Skewness & Kurtosis & C.R. \\
\hline sd1 & .40 & 1.06 & -.77 & .17 & .98 \\
sd2 & .33 & 1.04 & -1.29 & .81 & 4.72 \\
sd3 & .65 & .98 & -1.08 & .76 & 4.42 \\
sd4 & .56 & -1.04 & -1.02 & 49 & 2.86 \\
\hline
\end{tabular}


Table 4 Correlation values between observed variables

\begin{tabular}{lllllrrrrr}
\hline Variables & 1 & 2 & 3 & 4 & 5 & & $S D$ & Skew. & Kurt. \\
\hline Social distancing & 1 & & & & & 16.12 & 2.97 & -.75 & .43 \\
Depression & $-.19 * *$ & 1 & & & & 7.94 & 5.84 & .45 & -.74 \\
Anxiety & $-.23^{* *}$ & $.76^{* *}$ & 1 & & & 5.65 & 5.04 & .89 & .17 \\
Stress & $-.19 * *$ & $.85^{* *}$ & $.77 * *$ & 1 & & 8.69 & 5.62 & .27 & -.85 \\
Resilience & $.12^{* *}$ & $-.44^{* *}$ & $-.33^{* *}$ & $-.47 * *$ & 1 & 18.81 & 4.96 & -.08 & .18 \\
\hline
\end{tabular}

$* * p<.01$

of anxiety $\left(\chi^{2} / \mathrm{sd}=4.82, p<.001, \mathrm{CFI}=.90, \mathrm{RMSEA}=.07, \mathrm{GFI}=.92, \mathrm{AGFI}=.90, \mathrm{SRMR}=\right.$ .05 ), the results were found to have acceptable fit indices. According to the analysis of the structural equation model for the mediating effect of stress $\left(\chi^{2} / \mathrm{sd}=3.81, p<.001, \mathrm{CFI}=.93\right.$, RMSEA $=.06, \mathrm{GFI}=.94, \mathrm{AGFI}=.92, \mathrm{SRMR}=.06$ ), the results were found to have acceptable fit indices. The structural models for the analysis are presented in Fig. 2.

\section{Bootstrapping Process}

The significance of the direct and indirect effects of the variables in the model was examined through bootstrap analysis using 2000 repeated samples, as recommended by Arbuckle (2007). The direct and indirect coefficients resulting from the bootstrap analysis and the average effects within the 95\% confidence intervals for these coefficients are presented in Table 5. Significance was determined when the confidence interval did not include zero. Accordingly, it can be stated that all direct path coefficients are significant. The indirect path coefficient that allows the understanding of the mediating role was also found to be significant for depression $(\beta=.10, p<.01)$, anxiety $(\beta=.11, p<.01)$, and stress $(\beta=.11, p<.01)$. In light of these results, it can be said that depression, anxiety, and stress have a full mediator role in the relationship between social distancing and psychological resilience for people living in Turkey.

\section{Discussion}

This research aimed to carry out a validity and reliability study of an adaptation of Van Rooij et al.'s (2020) social distancing scale to the Turkish culture. The structure validity of the scale was examined by confirmatory factor analysis. This analysis is regarded as the most effective tool to evaluate whether the factor model in the original scale is compatible with the available data (Floyd and Widaman 1995). In confirmatory factor analysis, the relationships between latent and observed variables are indicated by arrow-shaped lines called "paths." The latent variables explain the observed variables in a given path by determining the weight of representation in the observed variables. This weight is indicated by the $\lambda$ (lambda) coefficient, which can be evaluated as the factor load value in exploratory factor analysis. A large $\lambda$ (lambda) value in CFA indicates a strong relationship between the latent variable and the observed variable (Çokluk et al. 2014). In this study, the calculated $\lambda$ values ranged from .38 to .89 , which are within acceptable limits. To determine whether these values are acceptable, the CR (critical ratio) values, accepted as $t$ values in the AMOS 20 program, were examined, and each item was found to be above the lower limit of 2.56 for significance at .01 level. The $t$ 
a)

$\mathrm{c}=.11$

Resilience

b)

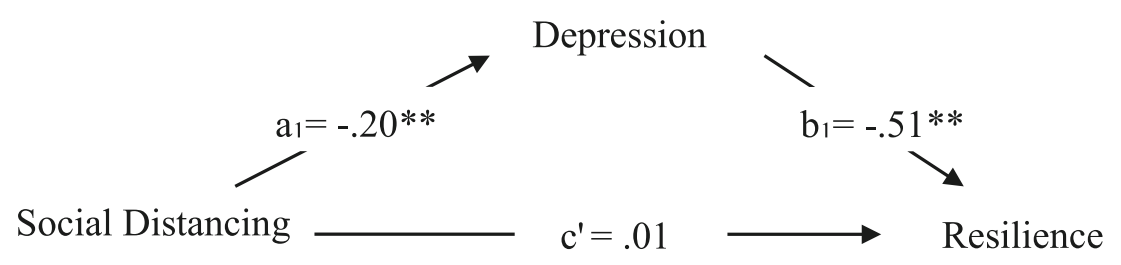

c)

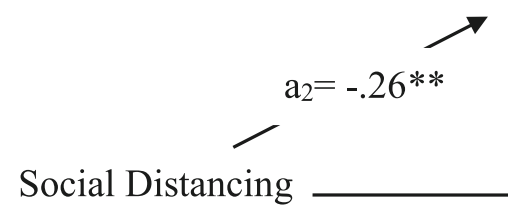

Anxiety

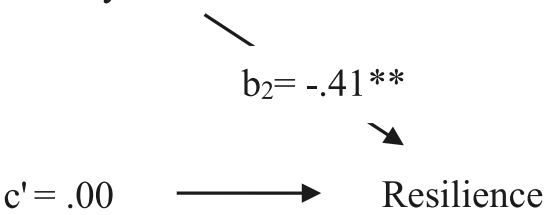

10

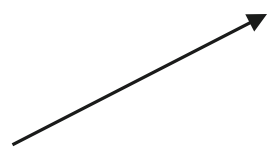

Stres

$$
\mathrm{a}_{3}=-.21 * *
$$

$\mathrm{b}_{3}=-.55 * *$

\section{Social Distancing}

Fig. 2 The indirect effects of depression, anxiety, and stress in the relationship between social distancing and psychological resilience (a, b, c, and d)

values of the items on the scale ranged from 4.61 to 19.75; thus, there was no need to remove any item from the scale. Statistics frequently preferred for confirmatory factor analysis of model-data fit are $\chi^{2} / \mathrm{sd}$, RMSEA, SRMR, GFI, AGFI, and CFI (Bayram 2016; Brown 2006). Model data compatibility is indicated by the fact that the calculated ratio of $\chi 2 / \mathrm{sd}$ was less than 5, RMSEA and SRMR values were lower than .08, and GFI, AGFI, and CFI values were greater than 90 (Bayram 2016; Brown 2006; Çokluk et al. 2014; Schumacker and Lomax 2010). These confirmatory factor analysis results indicate that the scale fits well as a singlefactor structure. 
Table 5 Bootstrapping process for full mediator model

\begin{tabular}{lccc}
\hline Model pathways & & $95 \%$ CI \\
\cline { 3 - 4 } Direct effect & Coefficient & Bottom & Top \\
\hline Social distancing $\rightarrow$ depression & $-.20^{* *}$ & -.28 &.-12 \\
Depression $\rightarrow$ resilience & $-.51^{* *}$ & -.58 & -.44 \\
Social distancing $\rightarrow$ resilience & $.11^{* *}$ & .02 & .19 \\
Social distancing $\rightarrow$ anxiety & $-.26^{* *}$ & -.34 & -.18 \\
Anxiety $\rightarrow$ resilience & $-.41^{* *}$ & -.48 & -.33 \\
Social distancing $\rightarrow$ resilience & $.11^{* *}$ & .02 & .19 \\
Social distancing $\rightarrow$ stress & $-.21^{* *}$ & -.29 & -.14 \\
Stress $\rightarrow$ resilience & $-.55^{* *}$ & -.62 & -.48 \\
Social distancing $\rightarrow$ resilience & $.11^{* *}$ & .02 & .20 \\
Indirect effect & & & .02 \\
Social distancing $\rightarrow$ depression $\rightarrow$ resilience & $.10^{* *}$ & .06 & .15 \\
Social distancing $\rightarrow$ anxiety $\rightarrow$ resilience & $.11^{* *}$ & 07 & .15 \\
Social distancing $\rightarrow$ stress $\rightarrow$ resilience & $.11^{* *}$ & .17 \\
\hline
\end{tabular}

Study 2 examined whether depression, anxiety, and stress played mediator roles in the relationship between social distance and resilience, by using a structural equation model. Accordingly, the results demonstrated that depression, anxiety, and stress have a fully mediating role in the relationship between social distancing and psychological resilience. In other words, the predictability of resilience of social distancing disappears when depression, anxiety, and stress variables are included in the model. This result is discussed below with regard to other studies in the literature.

A positive relationship was found between social distancing and psychological resilience. By following the social distancing rule, the risk of transmission of the virus decreases; thus, the psychological resilience of the individual may increase (Samuelson et al. 2020). Another finding result of the current study is that there is a negative significant relationship between the practice of social distancing and depression, anxiety, and stress, a result that corroborates many studies in the literature. The main changes in lifestyle and everyday habits are required to avoid infections, use of face masks outside the home, avoidance of touching face with hands, and social distancing. Ahorsu et al. (2020) showed that the fear of Covid-19 positively correlates with depression and anxiety. Previous research has demonstrated that individuals who obey and pay attention to the rules of social distancing experience fewer negative emotions and conditions such as depression, anxiety, and stress (Brooks et al. 2018; Choi et al. 2020; Cudjoe et al. 2020; Duan and Zhu 2020; Hawryluck et al. 2004; Jeong et al. 2016; Williams 2020; Wu et al. 2005; Zhou 2020). Brooks et al. (2020) stated that if unable to maintain social distancing, individuals are more likely to experience anxiety that may cause psychological problems. In addition, there are studies indicating that viruses such as MERS and SARS, which are members of the coronavirus family, increase anxiety and anger in individuals during epidemic periods (Jeong et al. 2016; Lee et al. 2016; Taylor et al. 2008). A study conducted by Jones and Salathe (2009) during the H1N1 epidemic concluded that an individual's level of anxiety played a mediator role in determining their avoidance behaviors, while Kristiansen et al. (2007) stated that the most careful behavior during such an epidemic is avoiding social contact. A study conducted by Çırakoğlu (2011) illustrated that avoidance behaviors can be predicted by the constant anxiety variable.

Psychological resilience, which is one of the concepts that are negatively related to stress and anxiety in the literature, is the ability of the individual to deal with pandemic illnesses and to adapt to 
the new situation (Basım and Çetin 2010; Masten and Coastworth 1998). Individuals with high psychological resilience are more successful in dealing with stressful factors than other people. Recent researches have shown that individuals with high resilience are more contentious in pandemic periods (Samuelson et al. 2020). In a study conducted in the UK during the Covid-19 pandemic in people with obesity problems, it was found that people with psychological resilience had low stress and anxiety and also had high healthy behaviors. These people have adapted more easily to quarantine and social distance rules (Le Brocq et al. 2020). In addition, previous research has also revealed a negative significant relationship between psychological resilience and anxiety and stress (Chow 2005). It was observed that there were positive significant relationships between perceived stress levels and difficulties encountered and coping with psychological resilience (Li et al. 2016; Nie et al. 2017; Üzar-Özçetin and Erkan 2019).

The most important result of study 2 and its contribution to the literature is the finding that depression, anxiety, and stress have a full mediator role in the relationship between social distancing and psychological resilience. According to this result, as the individuals comply with social distance rules, their psychological resilience levels increase. However, when the variables of depression, anxiety, and stress are included in this relationship, the psychological resilience of social distancing disappears. As a result, it can be said that the model put forward in the light of all these findings is acceptable.

\section{Limitations, Suggestions, and Conclusion}

Although the results of our investigation showed the social distancing scale to be a promising instrument, our results have some limitations. First, scale development and adaption studies are a process endless cycle (Kline 2011). Therefore, this findings ought to be regarded as preliminary. For this reason, future studies should maintain research of the psychometric properties of the social distancing scale. Second, although all our factor loads overran the minimum thresholds suggested by researchers (Dimitrov 2014), our two items (0.38 and 0.47) were lower than 0.50 . For this reason, validity and factor structure analyzes can be repeated with new studies.

This study examines the mediator roles that depression, anxiety, and stress play in the relationship between social distancing compliance and psychological resilience during the Covid-19 outbreak. The findings of the study are limited because the research relied only on quantitative measurement tools. The use of qualitative and mixed method measurement tools in future studies will facilitate a more in-depth examination of this subject. The other limitation of the research is methodologically caused by the inability to establish a cause-effect link. Although structural equation modeling, which is one of the most powerful techniques available for quantitative studies, is used within the scope of this research, longitudinal and experimental studies are needed to better explain the cause-effect link. To increase the generalizability of the results, we recommend translation of the social distancing scale into different languages, so as to test the expression model in different countries.

To conclude, the Covid-19 pandemic, which has affected many people worldwide, has negative effects on the psychological well-being of individuals. This study is the first to empirically present a structural model for Turkish people, in which the relationship between social distancing and resilience is fully mediated by depression, anxiety, and stress. Considering that nearly half a million Turkish people are infected with Covid-19 in Turkey, this study will provide an important contribution to the literature. 


\section{Appendix}

\section{Sosyal Mesafe Ölçeği Maddeleri}

\section{Beşli Likert tipi (1) "hiçbir zaman", (5) "her zaman"}

1- Aynı evde yașadığım insanlarla yüz yüze görüșüyorum.*

2- Aynı evde insanlar dışındakilerle güvenli bir mesafede duruyorum.

3- Aynı evde yaşamadığım insanları (akraba, arkadaş) ziyaret ediyorum.*

4- Aynı evde yaşamadığım insanların (akraba, arkadaş) beni ziyaret etmesine izin veriyorum.*

*Ters puanlanan maddeler.

\section{Social Distancing Scale Items}

\section{Likert scale ranging from (1) "never" to (5) "always"}

\section{1- I still meet people outside of my direct household.*}

2- I keep a safe distance from people outside of my direct household.

3- I still visit other (friends, relatives) outside of my direct houseshold.*

4- I still allow others (friends, relatives) to visit my direct household.*

* Reverse scored.

The participants indicate their level of agreement with the statements using a five-item Likert-type scale. Answers included "always," "very often," "sometimes," "rarely," and "never." The minimum score possible for each question is 1, and the maximum is 5. A total score is calculated by adding up each item score (ranging from 4 to 20). High scores obtained from the scale indicate that the individual pays attention to social distancing and follows social distance rules.

Acknowledgements We received no financial support for this investigation, authorship, and/or publication of this study.

\section{Declarations}

All procedures performed in studies involving human participants were in accordance with the ethical standards and with the Helsinki Declaration and its later amendments or comparable ethical standards.

Conflict of Interest The authors no conflict of interest.

Informed Consent Informed consent was obtained from all individual participants included in the study. We did not receive any financial support for the research, authorship, and/or publication of this article.

\section{References}

Adolph, C., Amano, K., Bang-Jensen, B., Fullman, N., \& Wilkerson, J. (2020). Pandemic politics: Timing statelevel social distancing responses to COVID-19. https:/www.medrxiv.org/content/10.1101/2020.03.30. 20046326v1

Agabi, C. E., \& Wilson, J. P. (2005). Trauma, PTSD, and resilience. Trauma, Violence, and Abuse, 6(3), $195-216$. 
Ahorsu, D. K., Lin, C. Y., Imani, V., Saffari, M., Griffiths, M. D., \& Pakpour, A. H. (2020) The Fear of COVID19 Scale: Development and initial validation. International Journal of Mental Health and Addiction, 1-15. Published online https://doi.org/10.1007/s11469-020-00270-8

Anderson, R. M., Heesterbeek, H., Klinkenberg, D., \& Hollingsworth, T. D. (2020). How will country-based mitigation measures influence the course of the COVID-19 epidemic? The Lancet, 395(10228), 931-934.

Arbuckle, J. L. (2007). Amos 16.0 user's guide. Spring House: Amos Development Corporation.

Asmundson, G. J., \& Taylor, S. (2020). Coronaphobia: Fear and the 2019-nCoV outbreak. Journal of Anxiety Disorders, 70, 1-3. https://doi.org/10.1016/j.janxdis.2020.102196.

Barnett-Howell, Z., \& Mobarak, A. M. (2020). The benefits and costs of social distancing in rich and poor countries. arXiv preprint arXiv:2004.04867.

Baron, R. M., \& Kenny, D. A. (1986). The moderator-mediator variable distinction in social psychological research: Conceptual, strategic, and statistical considerations. Journal of Personality and Social Psychology, 51(6), 1173-1182.

Basım, N. H., \& Çetin, F. (2010). Reliability and validity study of psychological resilience scale for adults [Yetișkinler için psikolojik dayanıklılık ölçeğinin güvenirlik ve geçerlik çalıșması]. Türk Psikiyatri Dergisi, 22, 1-13.

Bayram, N. (2016). Yapısal eşitlik modellemesine giriş AMOS uygulamaları. Bursa: Ezgi Yayıncılık.

Biçer, İ., Çakmak, C., Demir, H., \& Kurt, M. (2020). Coronavirus anxiety scale short form: Turkish validity and reliability study [Koronavirüs anksiyete ölçeği kısa formu: Türkçe geçerlik ve güvenirlik çalıșması]. Anatolian Clinic the Journal of Medical Sciences, 25(Special issue-COVID 19), 216-225. https://doi.org/ 10.21673/anadoluklin.731092.

Brooks, S. K., Dunn, R., Amlot, R., Rubin, G. J., \& Greenberg, N. (2018). A systematic, thematic review of social and occupational factors associated with psychological outcomes in healthcare employees during an infectious disease outbreak. Journal of Occupational and Environmental Medicine, 60(3), 248-257.

Brooks, S. K., Webster, R. K., Smith, L. E., Woodland, L., Wessely, S., Greenberg, N., \& Rubin, G. J. (2020). The psychological impact of quarantine and how to reduce it: rapid review of the evidence. The Lancet, 395, 912-920. https://doi.org/10.1016/S0140-6736(20)30460-8.

Brown, T. A. (2006). Confirmatory factor analysis for applied research. New York: Guilford Press.

Centers for Disease Control and Prevention [CDC], (2020). Covid-19 disease social distancing. https://www.cdc. gov/coronavirus/2019-ncov/prevent-getting-sick/social-distancing.html

Çeviker, S. A. \& Demiray, E. D. (2020). SARS-CoV-2 (COVID 19) Enfeksiyonu ayırıcı tanı açısından diğer solunumsal virüsler [Other respiratory viruses for differential diagnosis of SARS-CoV-2 (COVID 19) Infection]. Journal of Biotechnology and Strategic Health Research, 4(Spicial issue), 45-49. https://oi. org/10.34084/bshr.714383

Choi, N. G., Pepin, R. Marti, C. N., Stevens, C. J., \& Bruce, M. L. (2020). Improving social connectedness for homebound older adults: Randomized controlled trial of tele-delivered behavioral activation versus teledelivered friendly visits. Am Journal of Geriatr Psychiatry, 1-11. https://doi.org/10.1016/j.jagp.2020.02.008

Chow, H. P. H. (2005). Life satisfaction among university students in a Canadian Prairie City: A multivariate Analysis. Social Indicators Research, 70, 139-150.

Çırakoğlu, O. C. (2011). Domuz gribi (H1N1) salgınıyla ilişkili algıların, kaygı ve kaçınma düzeyi değişkenleri bağlamında incelenmesi [Investigation of perceptions associated with swine flu (H1N1) outbreak in the context of anxiety and avoidance level variables]. Türk Psikoloji Dergisi, 26(67), 49-64.

Çokluk, Ö., Șekercioğlu, G., \& Büyüköztürk, Ș. (2014). Sosyal bilimler için çok değişkenli istatistik: SPSS ve LISREL uygulamalart. Ankara: Pegem Akademi.

Cudjoe, T. K. M., Roth, D. L., Szanton, S. L., Wolff, J. L., Boyd, C. M., \& Thorpe, R. J. (2020). The epidemiology of social isolation: National health and aging trends study. Journals of Gerontology Series, B. Psyc. Sci. Soc. Sci., 75, 107-113.

Dağlı, A., \& Baysal, N. (2016). Yașam doyumu ölçeğinin Türkçe’ye uyarlanması: Geçerlik ve güvenirlik çalıșması [Adaptation of the satisfaction with life scale into Turkish: The study of validity and reliability]. Electronic Journal of Social Sciences, 15(59), 1250-1262.

De Pedraza, P., Guzi, M., \& Tijdens, K. (2020). Life Dissatisfaction and anxiety in Covid-19 pandemic. EUR 30243 EN, Publications Office of the European Union. 10.27.60/755327.

Deniz, Ö. P., \& Evci-Kiraz, E. D. (2020). Urban Health Studies in COVID-19 pandemic process [COVID-19 Pandemi sürecinde șehir sağlığı çalıșmaları]. Journal of Biotechnol and Strategic Health Research, 1(Special issu), 147-151.

Diener, E., Emmons, R. A., Larsen, R. J., \& Griffin, S. (1985). The satisfaction with life scale. Journal of Personality Assessment, 49(1), 71-75.

Dimitrov, D. M. (2014). Statistical methods for validation of assessment scale data in counseling and related fields. Alexandria, VA: John Wiley \& Sons. 
Doğan, T. (2015). Kısa psikolojik sağlamlık ölçeği’nin Türkçe’ye uyarlaması: Geçerlik ve güvenirlik çalıșması [Adaptation of the brief resilience scale into Turkish: A validity and reliability study]. The Journal of Happiness \& Well-Being, 3(1), 93-102.

Duan, L., \& Zhu, G. (2020). Psychological interventions for people affected by the COVID-19 epidemic. Lancet Psychiatry, 7(4). https://doi.org/10.1016/S2215-0366(20)30073-0.

Erarslan, Ö. (2014). Üniversite ögrencilerinde psikolojik sağlamlık ile depresif belirtiler ve yaşam memnuniyeti arasındaki ilișkide benlik saygısı, pozitif dünya görüşü ve umudun aracl rolünün incelenmesi [The investigation of the mediator role of positive views of self, world and future on the relationship of psychological resilience with depressive semptoms and life satisfaction in university students]. Unpublished master's thesis, Sosyal Bilimler Enstitüsü, Hacettepe Üniversitesi, Ankara, Turkey.

Fehr, A. R., \& Perlman, S. (2015). Coronaviruses: An overview of their replication and pathogenesis. In Coronaviruses (pp. 1-23). New York, NY: Humana Press.

Floyd, F. J., \& Widaman, K. F. (1995). Factor analysis in the development and refinement of clinical assessment instruments. Psychological Assessment, 7(3), 286-299. https://doi.org/10.1037/1040-3590.7.3.286.

Gizir, A. C. (2007). Psikolojik sağlamlık, risk faktörleri ve koruyucu faktörler üzerine bir derleme çalıșması [A review study on psychological resilience, risk factors and protective factors]. Turkish Journal of Psychological Counseling and Guidance, 3(28), 113-128.

Goodman, J. H. (2004). Coping with trauma and hardship among unaccompanied refugee youths from Sudan. Qualitative Health Research, 14(9), 1177-1196.

Gu, C., Jiang, W., Zhao, T., \& Zheng, B. (2020). Mathematical recommendations to fight against COVID-19. SSRN, https://ssrn.com/abstract=3551006 or https://doi.org/10.2139/ssrn.3551006

Hawryluck, L., Gold, W. L., Robinson, S., Pogorski, S., Galea, S., \& Styra, R. (2004). SARS control and psychological effects of quarantine, Toronto, Canada. Emerging Infectious Diseases, 10(7), 1206-1212.

Henry, J. D., \& Crawford, J. R. (2005). The short- form version of the depression anxiety stress scales (DASS21): Construct validity and normative data in a large non-clinical sample. British Journal of Clinical Psychology, 44(2), 227-239. https://doi.org/10.1348/014466505X29657.

Imai, N., Cori, A., Dorigatti, I., Baguelin, M., Donnelly, C. A., Riley, S., \& Ferguson, N. M. (2020). Report 3: Transmissibility of 2019-nCoV. https://www.imperial. ac.uk/media/imperial-college/medicine/sph/ide/gidafellowships/Imperial-2019-nCoV-transmissibility.pdf.

Jeong, H., Yim, H. W., Song, Y. J., Ki, M., Min, J. A., Cho, J., \& Chae, J. H. (2016). Mental health status of people isolated due to Middle East respiratory syndrome. Epidemiology and Health, 38, 1-7. https://doi.org/ 10.4178/epih.e2016048.

Jones, J. H., \& Salathe, M. (2009). Early assessment of anxiety and behavioral response to novel swine-origin influenza A (H1N1). PLoS one, 4(12), 832-840.

Karcıoğlu, Ö. (2020). What is coronaviruses, and how can we protect ourselves? Anka Tip Dergisi, 2(1), 66-71.

Kaya, B. (2020). Pandeminin ruh sağlığına etkileri [Effects of pandemic on mental health]. Klinik Psikiyatri Dergisi, 23, 123-124. https://doi.org/10.5505/kpd.2020.64325.

Kline, R. B. (2011). Principles and practice of structural equation modeling (Third ed.). New York: Guilford Press.

Kristiansen, I. S., Halvorsen, P. A., \& Gyrd-Hansen, D. (2007). Influenza pandemic: Perception of risk and individual precautions in a general population. Cross sectional study. BMC Public Health, 7, 48-55. https:// doi.org/10.1186/1471-2458-7-48.

Le Brocq, S., Clare, K., Bryant, M., Roberts, K., \& Tahrani, A. A. (2020). Obesity and Covid-19: A call for action from people living with obesity. The Lancet Diabetes \& Endocrinology, 8(8), 652-654.

Lee, D. H., Kim, J. Y., \& Kang, H. S. (2016). The emotional distress and fear of contagion related to Middle East respiratory syndrome (MERS) on general public in Korea. Korean Journal of Psychology General, 35(2), $355-383$.

Lewis, K. (2020). Covid-19: Preliminary data on the impact of social distancing on loneliness and mental health. Journal of Psychiatric Practice, 26(5), 400-404.

Li, M., Xu, J., He, Y., \& Wu, Z. (2012). The analysis of the resilience of adults one year after the 2008 Wenchuan earthquake. Journal of Community Psychology, 40(7), 860-870.

Li, G., Kong, L., Zhou, H., Kang, X., Fang, Y., \& Li, P. (2016). Relationship between prenatal maternal stress and sleep quality in Chinese pregnant women: The mediation effect of resilience. Sleep medicine, 25, 8-12.

Lovibond, P. F., \& Lovibond, S. H. (1995). The structure of negative emotional states: Comparison of the depression anxiety stress scales (DASS) with the Beck depression and anxiety inventories. Behavior Research and Therapy, 33(3), 335-343. https://doi.org/10.1016/0005-7967(94)00075-U.

Mahase, E. (2020). Coronavirus: Covid-19 has killed more people than SARS and MERS combined, despite lower case fatality rate. https://www.bmj.com/content/bmj/368/bmj.m641.full.pdf

Mahmoud, J. S. R., Staten, R. T., Hall, L. A., \& Lennie, T. A. (2012). The relationship among young adult college students' depression, anxiety, stress, demographics, life satisfaction, and coping styles. Issues in Mental Health Nursing, 33(3), 149-156. 
Masten, A. S., \& Coastworth, J. D. (1998). The development of competence in favorable and unfavorable environments: Lessons from research on successful children. American Psychologist, 53(2), 205-220.

McCubbin, M., Balling, K., Possin, P., Frierdich, S., \& Bryne, B. (2002). Family resiliency in childhood cancer. Family Relations, 51, 103-111.

Ministry of Interior [İçişleri Bakanlığı]. (2020). Koronavirüs tedbirleri konulu genelgesi [Circular on coronavirus measures]. https://www.icisleri.gov.tr/81-il-valiligine-koronavirus-tedbirleri-konulu-ek-genelge.

Ministry of National Education [MoNE], (2020). Okulların 30 Nisan 2020 tarihine kadar uzatılması kararı [The decision to extend the schools until April 30, 2020] https://www.meb.gov.tr/uzaktan-egitim-30-nisan.

Ministry of National Health [Sağlık Bakanlığı Halk Sağlığ1 Genel Müdürlüğü]. (2020). COVID-19 (SARSCoV2) Enfeksiyonu rehberi: Bilim kurulu çalışması [COVID-19 (SARSCoV2) Infection guide: Science board study]. https://hsgm.saglik.gov.tr/depo/covid19/ rehberler/COVID-19_RehberiV525Subat2020.pdf.

Morgan, G. A., Leech, N. L., Gloeckner, G. W., \& Barrett, K. C. (2004). SPSS for introductory statistics: Use and interpretation. Mahwah, NJ: Lawrence Erlbaum Associates.

Nakashima, M., \& Canda, E. R. (2005). Positive dying and resiliency in later life: A qualitative study. Journal of Aging Studies, 19(1), 109-125.

Nie, C., Dai, Q., Zhao, R., Dong, Y., Chen, Y., \& Ren, H. (2017). The impact of resilience on psychological outcomes in women with threatened premature labor and spouses: A cross-sectional study in Southwest China. Health and Quality of Life Outcomes, 15(26), 1-10.

Niu, Y., \& Xu, F. (2020). Deciphering the power of isolation in controlling COVID-19 outbreaks. Lancet Global Health, 8(4), 452-453.

Official Gazette of the Turkish Republic, (2020). Covid-19 kapsamında kamu çalıșanlarına yönelik tedbirler. https:/www.resmigazete.gov.tr/eskiler/2020/08/20200826-5.pdf

Özkoçak, V., Koç, F. \& Gültekin, T. (2020). Pandemilere antropolojik bakış: Koronavirüs (Covid-19) örneği [Anthropological overview of pandemics: Coronavirus (Covid-19) example]. Turkish Studies, 15(2), 11831195. https://doi.org/10.29228/TurkishStudies.42679

Pakpour, A. H., \& Griffiths, M. D. (2020). The fear of COVID-19 and its role in preventive behaviors. Journal of Concurrent Disorders. http://irep.ntu.ac.uk/id/eprint/39561/

Pueyo, T. (2020). "Coronavirus: Why you must act now” https://medium.com/@ tomaspueyo/coronavirus-acttoday-or-people-will-die-f4d3d9cd99ca

Rogowska, A. M., Kuśnierz, C., \& Bokszczanin, A. (2020). Examining anxiety, life satisfaction, general health, stress and coping styles during COVID-19 pandemic in Polish sample of university students. Psychology Research and Behavior Management, 13, 797-811.

Samuelson, K., Barthel, S., Colding, J., Macassa, G., \& Giusti, M. (2020). Urban nature as a source of resilience during social distancing amidst the coronavirus pandemic. https://doi.org/10.31219/osf.io/3wx5a

Schumacker, R. E., \& Lomax, R. G. (2010). A beginner's guide to structural equation modeling (3rd ed.). New York: Routledge.

Seçer, İ. (2015). SPSS ve LISREL ile pratik veri analizi, (2. Baskı). Ankara: Anı Yayıncılık.

Şimsek, O. F. (2007). Yapısal eşitlik modellemesine giriş (Temel ilkeler ve LISREL uygulamaları) [Introduction to structural equation modeling (Basic principles and LISREL applications)]. Ankara: Ekinoks.

Singh, C. B. (2020). Perceptual threat, social distancing, and well being of people during Covid-19 pandemic. International Journal of Human Potentials Management, 2(2), 35-50.

Smith, B. W., Dalen, J., Wiggins, K., Tooley, E., Christopher, P., \& Jennifer Bernard, J. (2008). The brief resilience scale: Assessing the ability to bounce back. International Journal of Behavioral Medicine, 15, $194-200$

Taylor, M. R., Kingsley, E. A., Garry, J. S., \& Raphael, B. (2008). Factors influencing psychological distress during a disease epidemic: Data from Australia's first outbreak of equine influenza. BMC Public Health, 8(11), 347-360. https://doi.org/10.1186/1471-2458-8-347.

Tian, H., Liu, Y., Li, Y., Wu, C. H., Chen, B., Kraemer, M. U., ... \& Wang, B. (2020). An investigation of transmission control measures during the first 50 days of the COVID-19 epidemic in China. Science, 368(6491), 638-642.

Trzebiński, J., Cabański, M., \& Czarnecka, J. Z. (2020). Reaction to the Covid-19 pandemic: The influence of meaning in life, life satisfaction, and assumptions on world orderliness and positivity. Journal of Loss and Trauma, 25(6), 544-557.

Uğraș-Dikmen, A., Kına, H. M., Özkan, S., \& İlhan M. N. (2020). Epidemiology of COVID-19: What we learn from pandemic? Journal of Biotechnology and Strategic Health Research 1(Special issue), 29-36. https:// doi.org/10.34084/bshr.715153

Üzar-Özçetin, Y. S. Ü., \& Erkan, M. (2019). Resilience, perceived stress and psychosocial health of high-risk pregnant women [Yüksek riskli gebelerde psikolojik sağlamlık, algılanan stres ve psikososyal sağlık]. Cukurova Medical Journal, 44(3), 1017-1026. 
Van Rooij, B., de Bruijn, A. L., Reinders Folmer, C., Kooistra, E., Kuiper, M. E., Brownlee, M., ... \& Fine, A. (2020). Compliance with Covid-19 mitigation measures in the United States.[Preprint].PsyArXiv:https://doi. org/10.31234/osf.io/qymu3

Walker, P. G., Whittaker, C., Watson, O. J., Baguelin, M., Winskill, P., Hamlet, A., ... \& Thompson, H. (2020). The impact of COVID-19 and strategies for mitigation and suppression in low-and middle-income countries. Journal of Science, 1-20. https://doi.org/10.1126/science.abc0035

Wilder-Smith, A., \& Freedman, D. O. (2020). Isolation, quarantine, social distancing and community containment: Pivotal role for old-style public health measures in the novel coronavirus (2019-nCoV) outbreak. Journal of Travel Medicine, 1-4. https://doi.org/10.1093/jtm/taaa020

Williams, B., (2020). Mental health concerns arise amid COVID-19 epidemic. Psychiatry advisor. https://www. psychiatryadvisor.com/home/topics/general-psychiatry/mental-health-concerns-arise-amid-covid-19epidemic/

World Health Organization [WHO], (2020). WHO characterizes COVID-19 as a pandemic. https://www.who. int/emergencies/diseases/novel-coronavirus-2020/events

Wu, K. K., Chan, S. K., \& Ma, T. M. (2005). Posttraumatic stress after SARS. Emerging Infectious Diseases, $11(8), 1297$.

Wu, J. T., Leung, K., \& Leung, G. M. (2020). Nowcasting and forecasting the potential domestic and international spread of the 2019-nCoV outbreak originating in Wuhan, China: A modeling study. Lancet, 395, 689-697.

Yılmaz, Ö., Boz, H., \& Arslan, A. (2017). Depresyon Anksiyete Stres Ölçeğinin (DASS 21) Türkçe kısa formunun geçerlilik-güvenilirlik çalıșması [The validity and reliability of depression stress and anxiety scale (DASS21) Turkish short form]. Finans Ekonomi ve Sosyal Araştırmalar Dergisi (FESA), 2(2), 78-91.

Zhang, S. X., Wang, Y., Rauch, A., \& Wei, F. (2020). Unprecedented disruption of lives and work: Health, distress and life satisfaction of working adults in China one month into the Covid-19 outbreak. Psychiatry Research, 288, 1-6. https://doi.org/10.1016/j.psychres.2020.112958.

Zhou, X. (2020). Psychological crisis interventions in Sichuan province during the 2019 novel coronavirus outbreak. Psychiatry Research, 286, 1-2. https://doi.org/10.1016/j.psychres.2020.112895.

Publisher's Note Springer Nature remains neutral with regard to jurisdictional claims in published maps and institutional affiliations. 